\title{
Performance and Carcass Quality of Broilers Supplemented With Antibiotics or Probiotics
}

Duthor(s)
Contreras-Castillo CJ1
Brossi C ${ }^{2}$
Previero TC 3
Demattê LC
1 Departamento de Agroindústria Alimentos
e Nutrição, Escola Superior de Agricultura
"Luiz de Queiroz".
2 Aluna mestranda do programa de pós-
graduação em Ciência e Tecnologia de
Alimentos da Escola Superior de Agricultura
"Luiz de Queiroz".
3 Aluno mestrando da Faculdade de Zootecnia
e Engenharia de Alimentos, Pirassununga,
SP, Brasil.
Departamento de Agroindústria Animal,
Korin Agropecuária Ltda., Ipeúna, SP, Brasil.

Mail Address

CJ Contreras-Castillo

Departamento de Agroindústria Alimentos e Nutrição

Escola Superior de Agricultura "Luiz de Queiroz"

Av. Pádua Dais, 11. CP 9

13.418-900. Piracicaba, SP, Brasil.

E-mail: ccastill@esalq.usp.br

\section{Keywords}

Additives, meat color, meat water holding capacity, polyprobiotics, zinc bacitracin.

\section{ABSTRACT}

The objective of this study was to evaluate the effects of different additives on broiler performance and meat quality. A total of 1620 oneday-old male Cobb broilers were distributed by a completely randomized experimental design into 5 treatments: positive control - zinc bacitracin (PC); negative control - without additives (NC); probiotic 1 - $10.000 \mathrm{~g} /$ ton (PR-I); probiotic 2 - $500 \mathrm{~g} /$ ton (PR-II); and probiotic 3 - $50 \mathrm{~g} /$ ton (PRIII). The PC treatment promoted better weight gain (WG) than PR-II (128 days) and PR-III (1-14; 1-28 days), better feed conversion (1-40 days period), and the highest WG among all treatments $(p<0.05)$. The performance of broilers fed probiotics was not different than those in the negative control group in any rearing phase, but there were performance differences among probiotic-treated birds. Hot and cold carcass yields and breast $\mathrm{pH}$ were not influenced by the different additives as compared to the negative control treatment. The only observed differences were in breast color $\left(a^{*}\right)$ and carcass yield between PR-III and the negative control group. Probiotics increased water holding capacity (except for PR-II) $(p<0.05)$. The treatment with antibiotic promoted the highest WG. Meat quality suffered little influence from the different additives.

\section{INTRODUCTION}

Research studies have reported feed residues in chicken meat products (Zaki et al., 2000) and the development of bacterial resistance to antibiotics used both in human medicine and poultry production (Edens, 2003; Zahrael et al., 2006). This concern led the European Union ban, since January 2006, the trade and use of antibiotics in foodproducing animals (Pecue, 2003). In Brazil, there is an increasing demand for good quality and health animal products (Bolis, 2002; Aguiar, 2006).

Probiotics (Edens, 2003; Timmerman et al., 2004) are additives that can be used to replace antibiotics in poultry nutrition (Revington, 2002; Griggs \& Jacob, 2005) and can be defined as a preparation of or a product containing viable, defined microorganisms in sufficient numbers, which alter the microflora in a compartment of the host and by that exert beneficial health effects in this host (Schrezenmeir \& De Vrese, 2001).

The inclusion of probiotics in the diet has shown to produce contradictory results on broiler performance. Researchers have reported positive (Maiorka et al., 2001; Correa et al., 2003; Dematte Filho, 2004) none or negative effects (Vargas, 2001; Lima et al., 2003; Pelicano et al., 2004; Flemming \& Freitas, 2005; Gunal et al., 2006) on broiler performance attributed to the action of probiotics. This variation in results was shown by Faria Filho et al. (2006) in their literature review. These authors indicate the need of further studies to verify the possible differences among probiotics sold in Brazil. 


\section{Contreras-Castillo CJ, Brossi C, Previero TC, Demattê LC}

Factors such as nutrition, stress, environment, use of vaccines and/or antibiotics, microorganism types, associations (different microorganisms in the same product - polyprobiotics) (Timmerman et al., 2004), and quantities may affect the action of the microorganisms present in the probiotic product, causing unexpected results in broiler performance (Edens, 2003; Menten \& Pedroso, 2005).

However, there are few studies that take into account the implications of the use of these additives on meat quality (Correa et al., 2003; Karaoglu et al., 2004; Aguiar, 2006; Huallanco, 2006). Therefore, the objective of the present experiment was to evaluate the effect of antibiotics or probiotics on the performance, carcass yield and quality of meat broilers.

\section{MATERIAL AND METHODS}

The experiment was carried out in the installation of the company Korin Agropecuária Ltda., Ipeúna, SP, Brazil, and the laboratory analyses were performed at the Meat Technology Lab of Escola Superior de Agricultura "Luiz de Queiroz" of the University of São Paulo, Piracicaba campus.

A total of 1620 non-vaccinated one day-old male Cobb broiler chicks was housed in a conventional broiler house. Birds were distributed according to a completely randomized experimental design into five treatments, with six replicates of 54 each, and at a density of 13 birds $/ \mathrm{m}^{2}$

Iso-nutritive feeds, based on corn and soybean meal, without animal by products and no inclusion of anticoccidials, were formulated according to rearing phase (Table 1). Feed was offered ad libitum. The diets were formulated by the company $\operatorname{Vaccinar}^{\circledR}$ according to the standards used in commercial farms, and to supply the nutritional requirements determined by Rostagno (2005) and the NRC (1994). The following treatments were applied: negative control - no additives (NC); positive control - zinc bacitracin (50 ppm), between 1-7 days; 60 ppm between 8-21 days, and 70 ppm between 22-40 days (PC); Probiotic $1-10.000$ g/ton (PR-I); Probiotic 2 - 500 g/ton (PR-II); Probiotic 3 $50 \mathrm{~g} /$ ton (PR-III). Additive inclusion levels followed the recommendation of the manufacturers (Table 1).

The following performance parameters were measured: feed intake (FI), weight gain (WG), and feed conversion ratio (FCR) for the cumulative periods of 1$14,1-28$, and 1-40 days of age. At the end of the experimental period (40 days), 90 birds per treatment were used for meat physical-chemical analyses and
Performance and Carcass Quality of Broilers Supplemented With Antibiotics or Probiotics

meat yield. All rearing and slaughter procedures were performed according the Ethical Principles of Animal Experimentation as recommended by the Brazilian College of Animal Experimentation. The yield of eviscerated carcasses with no feet, head, neck was calculated in relation to live weight before (hot carcass) and after chilling (cold carcass).

The following measurements were made: $\mathrm{pH}$ (average of 4 points - digital pHmeter Digimed DM2), instrumental color (average of 4 readings in the internal part of the muscle - Minolta CR300 colorimeter, 8-mm diameter measurement area, 10 observation angle, D65 illuminant and specular component), water holding capacity - WHC (according to the method of Nakamura \& Kataoh, 1985), cooking loss - CL (according to the method of Mead, 1987), and e shear force - SF (determined according to the technique described by Froning and Uijtteenboogart (1988), using the texturemeter Texture Test System coupled to a Warner-Bratzler apparatus with velocity of $20 \mathrm{~cm}$. min1 and load of $100 \mathrm{~kg}$. The results were expressed as $\mathrm{kgf} / \mathrm{cm}^{2}$, in breast meat samples (Pectoralis major) 24 hours after slaughter.

Performance and carcass yield and quality data were submitted to analysis of variance for a completely randomized experimental design. Means with significance level of $p<0.05$ ) were compared by the test of Tukey.

\section{RESULTS AND DISCUSSION}

Feed intake (FI) and weight gain (WG) of the birds fed probiotics were similar to those of the NC birds in all rearing stages, except for those fed PR-III in the period of 1-40 days, which WG was lower than the $N C$ birds $(p<0.05)$ (Table 2). Previous studies also found similar weight gain (Vargas et al., 2001; Lima et al., 2003; Pelicano et al., 2004) and feed intake (Pelicano et al., 2004; Flemming \& Freitas, 2005) in birds supplemented or not with probiotics. According to Pelicano et al. (2004), the similar or lower performance of birds fed probiotics as compared to negative control groups, may be due to an unbalance of the bird's gastrointestinal microflora consequent to the high number of microorganisms as compared to the quantities normally found in the digestive tract.

In the present experiment, no difference in the performance parameters between the PR-II treatment (which included only $B$. subtilis) as compared to the other treatments with probiotics (polyprobiotics), except for PR-III, which presented lower FI during the 


\section{Contreras-Castillo CJ, Brossi C, Previero TC, Demattê LC}

\begin{tabular}{|c|c|c|c|c|}
\hline Ingredients & $\begin{array}{l}\text { PRE-STARTER } \\
\text { (1 - } 7 \text { days) }\end{array}$ & $\begin{array}{c}\text { STARTER } \\
\text { (8 - } 21 \text { days) }\end{array}$ & $\begin{array}{c}\text { GROWER } \\
\text { (22 - 35 days) }\end{array}$ & $\begin{array}{c}\text { FINISHER } \\
\text { (36 - } 42 \text { days) }\end{array}$ \\
\hline Corn - grain (\%) & 58.04 & 62.15 & 69.47 & 71.68 \\
\hline Deactivated soybeans (\%) & 2.50 & 6.80 & 10.00 & 11.50 \\
\hline Soybean meal (\%) & 36.3 & 27.90 & 17.00 & 13.60 \\
\hline DL-Methionine (\%) & 0.08 & 0.05 & 0.09 & 0.05 \\
\hline L-Lysine (\%) & 0.03 & 0.05 & 0.09 & 0.12 \\
\hline Enzyme supp. $(\%)^{1}$ & 0.05 & 0.05 & 0.05 & 0.05 \\
\hline $\operatorname{Premix}(\%)^{2}$ & 3.00 & 3.00 & 3.00 & 3.00 \\
\hline \multicolumn{5}{|l|}{ Nutritional levels } \\
\hline Crude protein (\%) & 23.00 & 20.99 & 17.98 & 16.98 \\
\hline Fiber (\%) & 3.64 & 3.52 & 3.26 & 3.20 \\
\hline Ether extract (\%) & 3.00 & 3.95 & 4.78 & 5.13 \\
\hline Mineral matter (\%) & 5.22 & 4.91 & 4.50 & 4.52 \\
\hline ME poultry (kcal/kg) & 2.952 & 3.049 & 3.170 & 3.210 \\
\hline Total methionine (\%) & 0.57 & 0.55 & 0.50 & 0.37 \\
\hline Total Met + Cys (\%) & 0.96 & 0.91 & 0.81 & 0.67 \\
\hline Total lysine (\%) & 1.29 & 1.17 & 1.06 & 0.95 \\
\hline Sodium (mg/kg) & 1.767 & 1.743 & 1.721 & 1.712 \\
\hline Calcium (\%) & 0.89 & 0.78 & 0.89 & 0.87 \\
\hline Total phosphorus (\%) & 0.63 & 0.62 & 0.57 & 0.54 \\
\hline Dig. phosphorus (\%) & 0.39 & 0.38 & 0.35 & 0.32 \\
\hline Linoleic acid (\%) & 1.34 & 1.89 & 2.37 & 2.57 \\
\hline \multicolumn{5}{|c|}{ Composition of the probiotic products } \\
\hline Probiotic 1 & $\begin{array}{r}\text { Micro } \\
\text { Anaer } \\
\text { Lactose-ferme } \\
\text { Enter } \\
\text { Lactobaci }\end{array}$ & acteria & & $\begin{array}{l}\text { CFU/g } \\
1.0010^{6} \\
1.0010^{6} \\
1.0010^{6} \\
1.0010^{6}\end{array}$ \\
\hline Probiotic 2 & \multicolumn{2}{|c|}{ Bacillus subtilis } & \multicolumn{2}{|r|}{$>1.610^{9}$} \\
\hline Probiotic 3 & $\begin{array}{l}\text { Lactobac } \\
\text { Lactobac } \\
\text { Lactobac } \\
\text { Lactobac } \\
\text { Bifidobac } \\
\text { Streptococ } \\
\text { Enteroc }\end{array}$ & $\begin{array}{l}m \\
\text { is } \\
\text { is } \\
\text { is } \\
n \\
\text { ilus }\end{array}$ & & $\begin{array}{l}1.2610^{8} \\
2.0610^{8} \\
2.0610^{8} \\
2.0610^{8} \\
2.0010^{8} \\
4.1010^{8} \\
6.4610^{8}\end{array}$ \\
\hline
\end{tabular}

1 - Supplied at $0.0005 \mathrm{~g} / \mathrm{kg}$ feed: Betaglucanase $0.20 \mathrm{u} / \mathrm{g}$; Xylanase $0.14 \mathrm{u} / \mathrm{g}$; VitB2.15000 mg; Vit. B1 $500 \mathrm{mg}$; Vit. B6 1,000 mg; Vit. B12 15,000 mg; pantothenic acid 12,000 mg; niacin 20.000 mg; BHT 500 mg. 2- Supplied at 30 g/kg feed: Vit. D3 66,700 IU; Vit. E. 541 IU; Vit.A 267,000 IU; Vit.B1 36.5mg; Vit. B2.63 mg; Vit. B6 73mg; Vit. B12 570 mg; Vit. K3 81.5 mg; folic acid 18.5 mg; pantothenic acid 490 mg; biotin $1.8 \mathrm{mg}$; choline 8,850mg; methionine 41,580 mg; niacin 523 mg; Ca 236g; Co 33 mg; F 930 mgFe 2,478 mg; 23 mg; Mn 2.600 mg; Na 52 ;; P 85 mg; Se 6 mg; Zn 1.830 mg; BHT 87 mg.

period of $1-28$ days $(p<0.05)$. Therefore, the assertion of Timmerman et al. (2004) that probiotics containing several bacterial strains promoted better performance results was not confirmed here.

The group of birds fed zinc bacitracin (positive control) obtained, for the total rearing period (1-40 days), the highest $\mathrm{FI}$ as compared to the other treatments $(p<0.05)$ (Table 2$)$, whereas in the periods of 1-14 and 1-28 days, Fl of positive control group was similar to the probiotics groups 1 and 2, and higher than the NC and PR-III groups $(p<0.05)$.

The inclusion of the antibiotic in the feed also promoted higher weight gain (1-40 days) as compared to the other treatments $(p<0.05)$. These results are consistent with those found by Demattê Filho (2004) and Sugeta et al. (2004), but are opposite to those of Correa et al. (2003), Flemming \& Freitas (2005), and
Gunal et al. (2006). Considering the period of 1-14 days, the birds fed probiotics 1 e 2 had similar WG as to the birds in the PC treatment. For the period of 1-28 days, only PR-I WG was similar to the treatment that included the antibiotic. According to Demattê Filho (2004), the beneficial effect of antibiotics may be due to a possible change in the ratio between Gram-positive $(\mathrm{G}+)$ and Gram-negative (G-) bacteria present in the gastrointestinal tract, with an increase in $\mathrm{G}+$ and a decrease in G- bacteria.

NC feed conversion ratio during the period of 1-40 days was lower than in the PC and PR-I treatments $(p<0.05)$. FCR was not different among the other treatments. Considering the total rearing period, authors such as Vargas et al. (2001), Correa et al. (2003), and Flemming and Freitas (2005), also did not find statistical differences in FCR among experimental 


\section{Contreras-Castillo CJ, Brossi C, Previero TC, Demattê LC}

Performance and Carcass Quality of Broilers Supplemented With Antibiotics or Probiotics

\begin{tabular}{|c|c|c|c|c|c|c|c|c|c|}
\hline & \multicolumn{3}{|c|}{ 1-14 days } & \multicolumn{3}{|c|}{ 1-28 days } & \multicolumn{3}{|c|}{$1-40$ days } \\
\hline & $\begin{array}{l}\mathrm{FI} \\
(\mathrm{kg})\end{array}$ & $\begin{array}{l}\text { WG } \\
(\mathrm{kg})\end{array}$ & FCR & $\begin{array}{l}\text { FI } \\
(\mathrm{kg})\end{array}$ & $\begin{array}{l}\text { WG } \\
(\mathrm{kg})\end{array}$ & FCR & $\begin{array}{c}\mathrm{FI} \\
(\mathrm{kg})\end{array}$ & $\begin{array}{l}\text { WG } \\
(\mathrm{kg})\end{array}$ & FCR \\
\hline $\mathrm{CN}^{1}$ & $0.51 b$ & $0.38 b$ & $1.35 a b$ & $2.10 b c$ & $1.30 b$ & $1.62 a b$ & $4.03 b c$ & $2.36 b$ & $1.71 b$ \\
\hline$C P^{2}$ & $0.57 a$ & $0.44 a$ & $1.29 b$ & $2.27 a$ & $1.42 \mathrm{a}$ & $1.60 b$ & $4.48 a$ & $2.49 a$ & $1.80 a$ \\
\hline$P R-I^{3}$ & $0.54 a b$ & $0.40 a b$ & $1.36 a$ & $2.17 a b$ & $1.34 a b$ & 1.63ab & $4.23 b$ & $2.37 b$ & $1.78 a$ \\
\hline PR-II ${ }^{4}$ & $0.54 a b$ & $0.40 a b$ & $1.35 a b$ & $2.16 a b$ & $1.31 b$ & $1.65 a$ & $4.05 b c$ & $2.32 b c$ & $1.75 a b$ \\
\hline PR-III ${ }^{5}$ & $0.50 \mathrm{~b}$ & $0.37 b$ & $1.35 a b$ & $2.04 c$ & $1.25 b$ & $1.63 a b$ & $3.87 c$ & $2.23 c$ & $1.73 a b$ \\
\hline P & 0.0037 & 0.0021 & 0.0427 & 0.0002 & 0.0004 & 0.0785 & $<0.0001$ & $<0.0001$ & 0.0096 \\
\hline CV (\%) & 5.91 & 7.00 & 2.57 & 3.14 & 3.99 & 1.94 & 3.45 & 2.15 & 3.19 \\
\hline
\end{tabular}

$a, b, c$ - Means followed by different letters in the same column are different by the test of Tukey $(p<0.05) .1$ - NC: negative control. 2 - PC: positive control. 3 - PR-I: Probiotic 1. 4 - PR-II: Probiotic 2. 5 - PR-III: Probiotic 3.

groups supplemented with probiotics, antibiotics, or without antibiotics.

During the initial rearing stages, PC presented better FCR as compared to the groups probiotics 1 (1-14 days) and 2 ( $1-28$ days) $(p<0.05)$. FCR was not different among the other treatments during these periods. Better FCR during the first stages of rearing for broilers fed antibiotics as compared to those supplemented with probiotics was also observed by Demattê Filho (2004).

Considering the carcass yield, PR-III resulted in the lowest hot carcass yield relative to PC and PR-I $(p<0.05)$. PR-III also caused lower cold carcass yield as compared to $P C(p<0.05)$. There were no differences among the other treatments. Similar carcass yields in broilers supplemented or not with probiotics were found by Maiorka et al. (2001) and Correa et al. (2003).

In the present experiment, the parameters $L^{*}$ (lightness) and $b$ * (yellowness) were not influenced by additive supplementation (Table 3 ), as breast meat sample presented normal lightness values - between 50 and 56. Higher or lower values will cause dark or pale meat, respectively (Petracci et al., 2004), which are usually rejected by the consumers.

The breast meat of broilers fed PR-III obtained lower $a$ * (redness) values as compared to PC and NC treatments $(p<0.05)$, indicating a trend for paler color
(Table 3). However, according to Pelicano et al. (2003), $a^{*}$ values were significantly higher in the treatment with probiotics (4.52) than those in the negative control treatment (3.79), when meat was analyzed 45 minutes post mortem. Aguiar (2006) evaluated the breast meat of broilers raised under conventional, free-range, and natural (with probiotics) systems, and did not find any differences in $L^{*}$ and $a^{*}$ values among systems; however, the meat of natural broilers were considered less yellow (lower b* values) (Aguiar, 2006).

There was no influence of the applied treatments on $\mathrm{pH}$ values (Table 3 ) in the present experiment. Jones \& Grey (1989), Sams \& Mills (1993), and Aguiar (2006) found normal $\mathrm{pH}$ values at the end the post-mortem process of 5.60 to $5.80,5.78$ to 5.86 , and 5.75 to 5.96 , respectively. The $\mathrm{pH}$ results observed in the present experiment are within these ranges, independently of the use of probiotics. Therefore, the use of probiotics did not affect meat $\mathrm{pH}$.

WRC was not different between the probiotic and the PC groups, while the NC treatment resulted in lower WHC as compared to probiotics 1 and $3(p<0.05)$ (Table 3). The analysis of cooking loss (CL) also did not show any difference among treatments. In the study of Pelicano et al. (2003), no differences in WHC or CL were detected among the different probiotics tested,

Table 3 - Carcass yield (CY), color, pH, water retention capacity (WRC), cooking loss (CL), and shear force (SF) of breast meat according to treatment.

\begin{tabular}{|c|c|c|c|c|c|c|c|}
\hline & $\begin{array}{c}\text { Negative } \\
\text { control }\end{array}$ & $\begin{array}{l}\text { Positive } \\
\text { control }\end{array}$ & $\begin{array}{c}\text { Probiotic } \\
1\end{array}$ & $\begin{array}{c}\text { Probiotic } \\
2\end{array}$ & $\begin{array}{c}\text { Probiotic } \\
3\end{array}$ & $\mathbf{P}$ & CV (\%) \\
\hline \multicolumn{8}{|l|}{ Yield } \\
\hline RC quente (\%) & $67.61 a b$ & $68.84 a$ & $68.59 a$ & $67.32 a b$ & $66.74 b$ & 0.001 & 5.14 \\
\hline RC frio $(\%)$ & $71.06 a b$ & $72.64 a$ & 71.59ab & $70.86 a b$ & $70.88 b$ & 0.001 & 5.07 \\
\hline \multicolumn{8}{|l|}{ Cor } \\
\hline$L^{*}$ & $51.87 a$ & $51.54 a$ & $52.64 a$ & $51.15 a$ & $51.66 a$ & 0.413 & 5.18 \\
\hline$a^{*}$ & $3.42 \mathrm{a}$ & $3.38 \mathrm{a}$ & $2.90 a b$ & $3.19 a b$ & $2.42 b$ & 0.005 & 31.89 \\
\hline$b^{*}$ & $8.49 a$ & $8.61 a$ & $8.41 a$ & $8.69 a$ & $8.23 a$ & 0.868 & 15.97 \\
\hline $\mathrm{pH}$ & $5.83 a$ & $5.81 a$ & $5.83 a$ & $5.77 a$ & $5.83 a$ & 0.671 & 2.54 \\
\hline WRC (\%) & $48.81 b$ & $50.45 a b$ & $54.37 a$ & $52.41 a b$ & $57.16 a$ & 0.005 & 4.81 \\
\hline CL (\%) & $26.79 a$ & $27.09 a$ & $26.28 a$ & $28.57 a$ & $27.00 a$ & 0.873 & 13.04 \\
\hline SF (kgf/g) & $3.47 a$ & $3.01 \mathrm{~b}$ & $2.95 b$ & 3.39ab & $3.47 a$ & 0.047 & 17.96 \\
\hline
\end{tabular}

$a, b$ - Means followed by different letters in the same column are different by the test of Tukey $(p<0.05)$. 


\section{Contreras-Castillo CJ, Brossi C, Previero TC, Demattê LC}

Performance and Carcass Quality of Broilers Supplemented With Antibiotics or Probiotics or between probiotics and the control treatment. According to Dabés (2001), lower WHC implies in nutrient losses in the exsudate, resulting in a drier and, therefore, less tender meat.

When the objective meat tenderness (shear force) was assessed, the breast meat of broilers in treatments NC and PR-III presented the lowest tenderness, and were significantly different from the meat of broilers in treatments PC and PR-I, which were the tenderest. However, Pelicano et al. (2003) did not find any statistical difference in shear force between the negative control and treatments with different probiotics. Lyon \& Lyon (1990) related objective tenderness to sensorial assessment, and observed that, for acceptable chicken breast meat tenderness, a shear force value of $8.8 \mathrm{kgf} / \mathrm{g}$ meat sample was considered as "very tough", and values below $3.6 \mathrm{kgf} / \mathrm{g}$ were appraised as "very tender". Therefore, taking into account the range of shear force values obtained in the present experiment ( 2.9 to $3.4 \mathrm{kgf} / \mathrm{g}$ ), the use of probiotics did not have a significant influence on meat tenderness.

\section{CONCLUSIONS}

The performance of broilers in the groups supplemented with probiotics was similar among these groups and to those in the negative control treatment, but lower than those in positive control group (supplemented with antibiotic). The use of probiotics had little influence on meat quality, and no negative effects on color parameters, $\mathrm{pH}$, drip loss, or tenderness.

\section{REFERENCES}

Aguiar APS. Opinião do consumidor e qualidade de carne de frangos criados em diferentes sistemas de produção [dissertação]. Piracicaba (SP): Escola Superior de Agricultura "Luiz de Queiroz", Universidade de São Paulo; 2006.

Bolis DA. Analise de mercado para frangos orgânicos [dissertação]. Joaçaba (SC): Faculdade de Administração, Universidade do Oeste de Santa Catarina; 2002.

Corrêa GSS, Gomes AVC, Corrêa AB, Salles AS, Mattos ES. Efeito de antibiótico e probiotics sobre o desempenho e rendimento de carcaça de frangos de corte. Arquivo Brasileiro de Medicina Veterinária e Zootecnica 2003; 55(4):467-473.

Dabés AC. Propriedades da carne fresca. Revista Nacional da Carne 2001; 25(288):32-40.

Demattê Filho LC. Aditivos em dietas para frangos de corte, criados em sistema alternativo [dissertação]. Botucatu(SP): Universidade Estadual Paulista; 2004.

Edens FW. An alternative for antibiotic se in poultry: probiotics. Revista Brasileira de Ciência Avícola 2003; 5(2):75-97.

Faria Filho DE, Torres KA, Faria DE, Campos DMB, Rosa PS. Probiotics for broiler chickens in Brazil: systematic review and meta-analysis. Revista Brasileira de Ciência Avícola 2006; 8(2):89-98.

Flemming JS, Freitas RJS. Avaliação do efeito de prebióticos (mos), probiotics (Bacillus licheniformis e Bacillus subtilis) e promotor de crescimento na alimentação de frangos de corte. Archives of Veterinary Science 2005; 10(2):41-47.

Froning GW, Uijttenboogaart TG. Effect of post mortem electrical stimulation on color, texture, $\mathrm{pH}$, and cooking loses of hot and cold deboned chicken broiler breast meat. Poultry Science 1988; 67(11):1536-44.

Griggs JP, Jacob JP. Alternatives to antibiotics for organic poultry production. The Journal of Applied Poultry Research 2005; 14: 150-156.

Gunal M, Yayli G, Kaya O, Karahan N, Sulak O. The effects of antibiotic growth promoter, probiotic or organic acid supplementation on performance, intestinal microflora and tissue of broilers. International Journal of Poultry Science 2006; 5(2):149155.

Huallanco MBA. Aplicação de um sistema de classificação de carcaças e cortes e efeito pós-abate da qualidade de cortes de frangos criados no sistema alternativo [dissertação]. Piracicaba (SP): Escola Superior de Agricultura "Luiz de Queiroz", Universidade de São Paulo; 2006.

Jones JM, Grey TC. Influence of processing on product quality and yield. In: Mead GC, editor. Processing of poultry. London: Chapman \& Hall; 1989. p. 127-130.

Karaoglu M, Aksu MI, Esenbuga N, Kaya M, Macit M, Durdag H. Effect of dietary probiotic on the $\mathrm{pH}$ and colour characteristics of carcasses, breast fillets and drumsticks of broilers. Animal Science 2004; 78(2):253-259.

Lima ACF, Pizauro-Júnior JM, Macari M, Malheiros EB. Efeito do uso de probiotic sobre o Desempenho e atividade de enzimas digestivas de frangos de corte. Revista Brasileira de Zootecnia 2003; 32(1):200-207.

Lyon CE, Lyon BG. The relationship of objective shear values and sensory tests to changes in tenderness of broiler breast meat. Poultry Science 1990; 69:1420-1427.

Maiorka A, Santin E, Sugeta SM, Almeida JG, Macari M. Utilização de Prebióticos, probiotics ou simbióticos em dietas para frangos. Revista Brasileira de Ciência Avícola 2001; 3(1):75-82.

Mead GS. Recommendation for a standardized method of sensory analyzis for broilers. World's Poultry Science Journal 1987; 43(1): 64-67.

Menten JFM, Pedroso AA. Fatores que interferem na eficácia de 


\section{Contreras-Castillo CJ, Brossi C, Previero TC, Demattê LC}

probiotics. Anais da Conferência APINCO de Ciências e Tecnologia Avícolas; 2005; Santos, São Paulo, Brasil. v. 1, p. 41-52.

Nakamura M, Katoh K. Influence of thawing method on several properties of rabbit meat. Bulletin of Ishikawa Prefecture College of Agriculture 1985; 11(1):45-49.

National Research Council. Nutrient requirements of poultry. 9th ed. Washington: National Academy Press; 1994.

Parlamento Europeu E O Conselho Da União Europeia, Regulamento (CE) n. 1831/2003. Jornal Oficial da União Européia, 22 set 2003[online]. [citado em 30 out 2006]. Disponível em: http:// europa.eu.

Pelicano ERL, Souza PA, Souza HBA, Oba A, Norkus EA, Kodawara LM, Lima TMA. Effect of different probiotics on broiler carcass and meat quality. Revista Brasileira de Ciência Avícola 2003; 5(3):207214.

Pelicano ERL, Souza PA, Souza HBA, Oba A, Norkus EA, Kodawara LM, Lima TMA. Performance of broilers fed diets containing natural growth promoters. Revista Brasileira de Ciência Avícola 2004; 6(4): 231-236.

Petracci M, Betti M, Bianchi M, Cavani C. Color variation and characterization of broiler breast mat during processing in Italy. Poultry Science 2004; 83(12):2086-2092.

Revington B. Feeding poultry in the post-antibiotic era [online].[citado em 31 out 2006]. Disponível em: http:// ag.ansc.purdue.edu/poultry/multistate/Multi-state.pdf

Rostagno HS, Albino LTF, Donzele JL. et al. Tables brasileiras para aves e suinos: composição de alimentos e exigências nutricionais. Vicosa: UFV; 2005. 186p.

Sams AR, Mills KA. The effect of feed withdrawal duration on the responsiveness of broiler pectoralis to rigor mortis acceleration. Poultry Science 1993; 72(9):1789-1796.

Schrezenmeir J, De Vrese M. Probiotics, prebiotics, and synbiotics approaching a definition. The American Journal of Clinical Nutrition 2001; 73:361S-364S. Supl.

Sugeta SM, Bersch FX, Bueno CJC, Borges CAQ. Substituição dos promotores de crescimento por probiotics na dieta de frangos de corte. Revista Brasileira de Ciência Avíco; Supl 6:53.

Timmerman HM, Koning CJ, Mulder L, Rombouts FM Beynen AC. Monostrain, multistrain and multispecies probiotics: A comparison of functionality and efficacy. International Journal of Food Microbiology 2004; 96(3):219-233.

Vargas JG, Toledo RS, Albino LFT, Rostagno HS, Carvalho DCO, Oliveira JE. Uso de probiotics, prebióticos e antibióticos em rações de frango de corte. Anais ds $38^{a}$ Reunião Anual da Sociedade Brasileira de Zootecnia; 2001; Piracicaba, São Paulo. Brasil. p. 819820. 